\title{
Solid State Anaerobic Digestion for Biogas Production from Rice Husk
}

\author{
Hashfi Hawali Abdul Matin ${ }^{1,4 *}$, Syafrudin Syafrudin'², and Suherman Suherman ${ }^{3}$ \\ ${ }^{1}$ School of Post Graduate Studies, Diponegoro University, Indonesia \\ ${ }^{2}$ Department of Environmental Engineering, Faculty of Engineering, Diponegoro University, Indonesia \\ ${ }^{3}$ Department of Chemical Engineering, Faculty of Engineering, Diponegoro University, Indonesia \\ ${ }^{4}$ Department of Environmental Science, Faculty of Mathematic and Natural Science, Sebelas Maret University, \\ Indonesia
}

\begin{abstract}
Increased rice production in Indonesia not only brings good news socially and economically, but also brings bad news for environmental ecology. In each rice crop produces $50 \%$ rice straw and $50 \%$ grain. The grain is divided into two again, namely $80 \%$ rice and $20 \%$ rice husk. In 2018 , counted the rice husk up to $10,379,625$ tons, a fantastic number if cannot be managed properly so that it can pollute the environment. One alternative to deal with the high rice husk is through conversion to biogas. Biogas is an energy that is formed under anaerobic conditions with organic material so that it is also called renewable energy. The development of research on biogas production from rice husks based SS-AD has experienced a positive increase in hardness. Studies have been conducted on the pre-treatment to other influencing factors. But after the authors describe the latest development of biogas research from rice husk, there are still some variables that have not been tested such as physical treatment, the influence of temperature, $\mathrm{pH}$ and alkalinity. Based on this review, further research is needed to complete a number of variables that have not been carried out so that it is expected that the development of biogas production from rice husk based SS-AD can move toward larger scales such as pilot scale and industrial scale.
\end{abstract}

\section{Introduction}

As an agrarian country, Indonesia has a variety of activities in agriculture. One of the agricultural activities is rice farming. Rice plants produce rice where rice is a staple food for the people of Indonesia. Because of the high demand for rice, many farmers in Indonesia prefer to grow rice rather than other crops. Rice plants are very easy to live in Indonesia because of the climate and suitable soil. In general, rice is suitable for climates with little heat and contains a lot of water vapor and with soil content varies from sand to clay.

The agricultural industry has brought widespread social and economic improvement for the perpetrators. In 2018, Indonesia was able to produce $83,037,000$ tons of rice with a harvest area of 15,995,000 hectares spread throughout Indonesia, with details of the

* Corresponding author: hawalihashfi@gmail.com 
development of the last four years presented in table 1 [1]. The rice harvest production data is a very good achievement and its productivity will continue to increase along with the Indonesian government's policy to become a country of self-sufficiency in rice. The policy will slowly suppress rice import activities and become a trigger for Indonesia to become a rice exporting country.

Table 1. Production, Harvest Area and Rice Productivity in Indonesia in 2014-2018

\begin{tabular}{lccccc}
\hline \multicolumn{1}{c}{ Commodity } & \multicolumn{5}{c}{ Year } \\
\cline { 2 - 6 } & $\mathbf{2 0 1 4}$ & $\mathbf{2 0 1 5}$ & $\mathbf{2 0 1 6}$ & $\mathbf{2 0 1 7}$ & $\mathbf{2 0 1 8}$ \\
\hline Rice plants & & & & & \\
Production (000 Ton) & 70,846 & 75,398 & 79,355 & 81,149 & 83,037 \\
Harvested area (000 & 13,797 & 14,117 & 15,156 & 15,712 & 15,995 \\
Ha) & 51.35 & 53.41 & 52.36 & 51.65 & 51.92 \\
Productivity (Ku/Ha) & & & & & \\
\hline
\end{tabular}

Increased rice production in Indonesia not only brings good news socially and economically, but also brings bad news for environmental ecology. In each rice crop produces $50 \%$ rice straw and $50 \%$ grain. Of the grain itself is divided into two again, namely $80 \%$ rice and $20 \%$ rice husk [2]. All rice produced is sold by farmers and is a staple food for Indonesians. For rice husk, it will usually be used by brick craftsmen as fuel to burn bricks. Other uses are also carried out by plant sellers, which are used as planting media for plants. The results of the remaining rice in the form of rice husk have been used for several activities but not all of them have been utilized. Therefore, farmers burn the rice husk because they are confused about managing them. Whereas on the other hand, rice husk burning can disrupt human health and cause a decrease in air quality in the area and can reduce nutrients in the land where rice husk is burned.

The activity of burning rice husk can be stopped by making maximum use of these materials. Other utilization of rice husk in addition to raw materials for burning bricks and as a planting medium is to use them as raw materials for anaerobic biogas formation. Biogas is an energy that is formed under anaerobic conditions with organic material so that it is also called renewable energy [3-6]. Biogas is not only used directly for gas, but can also be converted into electricity and heat energy [7].

\section{Rice Husk}

Rice husk is one of the waste produced from agricultural activities, namely rice plants. Rice plants can be harvested every 3-4 months. In each harvest cycle, rice plants produce several kinds of by-products other than the main product, which is rice that is usually consumed by the people like in Indonesia. Rice plants at every harvest will produce side products such as rice straw and rice husk [8]. Rice straw is usually used as animal feed ingredients while rice husk is only used as a planting medium and as an additional fuel in making bricks. Every harvest, the rice plant will produce rice straw and grain as much as 1: 1, then the grain will be ground in the rice mill and produce rice and rice husk 4: 1 [9]. If you look at table 1 where the productivity of rice in 2018 in Indonesia can reach 83,037,000 tons, then the other side of it is the high rice husk that arises, if it is calculated to reach $10,379,625$ tons of rice husk in 2018, a fantastic number if cannot be managed properly so that it can pollute the environment.

In its handling, rice husks are included in biomass which is difficult to be degraded by microorganisms. The physical characteristics of rice husk are hard and dry with a component of cellulose 59\%, Hemicellulose 18\%, Lignin 21\%, and Ash about 2\% [10-12]. Lignin 
content in rice husk is believed to inhibit microorganisms in the decomposition process so that if the rice husk is left alone it is placed somewhere then the husk remains intact without experiencing decay. This is one of the variables that must be considered so that the aerobic biogas production process can run well, so preliminary treatment of rice husks is needed before entering the digester.

\section{Pre-treatment of Rice Husk for Biogas}

Anaerobic digestion technology has proven successful in producing biogas. Many researchers have produced biogas with various raw materials such as cow dung, goat dung, pig dung, poultry droppings, household organic waste, corncobs, sugarcane bagasse, and many more. This is inseparable from the initial treatment of each of these raw materials. There is a physics with enumeration, biologically with the addition of enzymes to accelerate the biochemical process, to chemically by immersing raw materials on several types of chemicals with various concentrations and length of time. [8, 13, 22, 23], [14-21].

In the past 5 years, there are several researchers who conducted research on biogas production with rice husk raw material. Pre-treatment is needed as an effort to increase biogas production. The pre-treatment techniques that have been used are physics, chemistry and biology. First, [24] states that biological treatment by adding 5\% enzyme and chemical treatment using $3 \% \mathrm{NaOH}$ can increase biogas production. Then by [25] states that biological treatment using 5\% enzyme can increase biogas production. Furthermore [6] also stated in his research, conducted research on the effect of chemical treatment with $\mathrm{NaOH}$ in the range of $3-9 \%$, the best results obtained were $6 \% \mathrm{NaOH}$. In addition, research was conducted on the effect of biological treatment with enzymes in the range of $5-11 \%$, the best results were obtained on enzymes of $11 \%$. Another study is [21], conducting research on chemical treatment using $\mathrm{CH}_{3} \mathrm{COOH}$ in the range of $3-5 \%$, the best results were obtained at $3 \%$ $\mathrm{CH}_{3} \mathrm{COOH}$. Then an experiment using 3-5\% range $\mathrm{HNO} 3$ was carried out, but the biogas yield was low, lower than the $\mathrm{CH}_{3} \mathrm{COOH}$ treatment experiment and without treatment at all. Then [9], stated that chemical preliminary treatment using $3 \% \mathrm{NaOH}$ could increase biogas production 4.5 times higher and biological treatment with enzymes in the range of 3-9\% obtained the best biogas productivity at $6 \%$ enzyme. More concisely, the preliminary treatment of rice husks for biogas production can be seen in Table 2.

Table 2. Pre-treatment for Biogas Production

\begin{tabular}{|c|c|c|c|}
\hline Treatment & Substrate & Condition & Result \\
\hline \multirow{5}{*}{$\mathrm{NaOH}$} & Rice husk & $\begin{array}{l}\mathrm{SS}-\mathrm{AD} \mathrm{TS} 21 \%, \mathrm{C} / \mathrm{N} \\
\text { ratio } 20-35, \mathrm{NaOH} 3 \%\end{array}$ & $\begin{array}{l}3 \% \mathrm{NaOH} \text { increases } \\
\text { biogas production }\end{array}$ \\
\hline & Rice husk & SS-AD TS $21 \%, \mathrm{C} / \mathrm{N}$ & The best biogas \\
\hline & & ratio $25, \mathrm{NaOH} 3-9 \%$ & $\begin{array}{l}\text { production is in } \\
\text { variables with } 3 \%\end{array}$ \\
\hline & & & $\mathrm{NaOH}$, which is $497 \mathrm{ml}$ \\
\hline & Rice husk & $\begin{array}{l}\text { SS-AD TS } 15-40 \%, \mathrm{C} / \mathrm{N} \\
\text { ratio } 20-50, \mathrm{NaOH} 3 \%\end{array}$ & $\begin{array}{l}3 \% \mathrm{NaOH} \text { increases } \\
\text { biogas production } 4.5 \\
\text { times higher than } \\
\text { variables } \\
\mathrm{NaOH} \text { without } \\
\end{array}$ \\
\hline $\mathrm{CH}_{3} \mathrm{COOH}$ & Rice husk & $\begin{array}{l}\text { SS-AD TS } 21 \% \text {, room } \\
\text { temperature, } \mathrm{CH}_{3} \mathrm{COOH} \\
3-5 \%\end{array}$ & $\begin{array}{l}\text { Biogas production with } \\
3 \% \mathrm{CH}_{3} \mathrm{COOH} \text { is higher } \\
\text { than } 5 \% \text {, which is } 45.86 \\
\text { ml/gr.TS }\end{array}$ \\
\hline
\end{tabular}




\begin{tabular}{|c|c|c|c|}
\hline $\mathrm{HNO}_{3}$ & Rice husk & $\begin{array}{l}\mathrm{SS}-\mathrm{AD} \text { TS } 21 \% \text {, room } \\
\text { temperature, } \mathrm{HNO}_{3}\end{array}$ & $\begin{array}{l}\text { Biogas production with } \\
3 \% \text { HNO3 is higher } \\
\text { than 5\%, which is } 21.85 \\
\text { ml/gr.TS. This pre- } \\
\text { treatment results are } \\
\text { very low, because it is } \\
\text { lower than the variable } \\
\text { without treatment }\end{array}$ \\
\hline \multirow{4}{*}{ Enzyme } & Rice husk & $\begin{array}{l}\mathrm{SS}-\mathrm{AD} \quad \mathrm{TS} \quad 21 \%, \mathrm{C} / \mathrm{N} \\
\text { ratio } 20-35, \text { Enzyme } 5 \%\end{array}$ & $\begin{array}{lr}5 \% \text { enzyme } & \text { can } \\
\text { increase } & \text { biogas } \\
\text { production } & \\
\end{array}$ \\
\hline & Rice husk & $\begin{array}{l}\mathrm{SS}-\mathrm{AD} \mathrm{TS} 21 \%, \mathrm{~F} / \mathrm{M} \\
\text { ratio } 6-24, \mathrm{C} / \mathrm{N} \text { ratio } 25, \\
\text { Enzyme } 5 \%\end{array}$ & $\begin{array}{lr}5 \% \text { enzyme } & \text { can } \\
\text { increase } & \text { biogas } \\
\text { production } & \\
\end{array}$ \\
\hline & Rice husk & $\begin{array}{l}\mathrm{SS}-\mathrm{AD}, \mathrm{TS} 21 \%, \mathrm{C} / \mathrm{N} \\
\text { ratio } 25, \text { Enzyme } 5-11 \%\end{array}$ & $\begin{array}{l}\text { The best biogas } \\
\text { production is in } \\
\text { variables with } 11 \% \\
\text { enzyme, which is } 667.5 \\
\text { ml }\end{array}$ \\
\hline & Rice husk & $\begin{array}{l}\text { SS-AD TS } 15-40 \%, \mathrm{C} / \mathrm{N} \\
\text { ratio } 20-50, \text { Enzyme } 3- \\
9 \%\end{array}$ & $\begin{array}{l}\text { The best biogas } \\
\text { production results are } \\
\text { seen in variables with } \\
6 \% \text { enzyme following } \\
\text { other variables such as } \\
\mathrm{CN} \text { ratio and TS } \\
\text { concentration using } \\
\text { response surface } \\
\text { methodology (RSM) }\end{array}$ \\
\hline
\end{tabular}

\section{Factors Affecting Biogas from Rice Husk}

There are factors that can affect biogas production from anaerobic digestion. Whatever the raw material for biogas, the influencing factors are the same. Because the biogas production base is biologically, these factors are the same as the factors that influence the growth of anaerobic bacteria, including $\mathrm{C} / \mathrm{N}$ ratio, total solid (TS), $\mathrm{pH}$, temperature, alkalinity, $\mathrm{F} / \mathrm{M}$ ratio [26, 27], [36-38], [28-35].

So far there has been research on biogas production from rice husk on these factors. In research on the effect of $\mathrm{CN}$ ratio conducted by [24] in the range of 20-35, obtained the best biogas productivity at a $\mathrm{CN}$ ratio of 35 . Furthermore [25] in his research on the effect of FM ratio in the range of 6-24, obtained the best biogas productivity on $\mathrm{CN}$ ratio 10 . For the effect of TS, [39] in his research on TS in the range 17-23\% (SS-AD conditions), obtained the best biogas productivity at TS $23 \%$ per unit volume and TS $17 \%$ per unit weight (grams). Furthermore, [9] also conducted a study on the effect of CN ratio in the range of 20-50 with the help of Response Surface Methodology, in the study it was found that the best biogas productivity was $\mathrm{CN}$ ratio 35 . Experiments were also conducted on TS with a range of 15$40 \%$ (SS-AD conditions), the best biogas productivity is obtained at TS $27 \%$. More concisely, the results of research on the factors that influence biogas production from rice husks can be seen in Table 3. 
Table 3. Factors Affecting Biogas Production

\begin{tabular}{|c|c|c|c|}
\hline Factor & Substrate & Condition & Result \\
\hline \multirow{2}{*}{$\mathrm{C} / \mathrm{N}$ ratio } & Rice husk & $\begin{array}{l}\mathrm{SS}-\mathrm{AD} \mathrm{TS} 21 \%, \mathrm{C} / \mathrm{N} \\
\text { ratio 20-35, Pre-treatment } \\
\mathrm{NaOH} 3 \% \text { and enzyme } \\
5 \%\end{array}$ & $\begin{array}{l}\text { The best biogas } \\
\text { productivity in the } \\
\text { variable } \mathrm{C} / \mathrm{N} \text { ratio } 35\end{array}$ \\
\hline & Rice husk & $\begin{array}{l}\mathrm{SS}-\mathrm{AD} \text { TS } 15-40 \%, \mathrm{C} / \mathrm{N} \\
\text { ratio } 20-50, \text { Pre-treatment } \\
\mathrm{NaOH} 3 \% \text { and Enzyme } \\
6 \%\end{array}$ & $\begin{array}{l}\text { The best biogas } \\
\text { productivity at } \mathrm{C} / \mathrm{N} \\
\text { ratio } 35 \text { with TS } 27 \%\end{array}$ \\
\hline $\mathrm{F} / \mathrm{M}$ ratio & Rice husk & $\begin{array}{l}\mathrm{SS}-\mathrm{AD} 21 \%, \mathrm{C} / \mathrm{N} \text { ratio } \\
25, \mathrm{~F} / \mathrm{M} \text { ratio } 6-24, \text { Pre- } \\
\text { treatment Enzyme } 5 \%\end{array}$ & $\begin{array}{l}\text { The best biogas } \\
\text { productivity in the } \\
\text { variable } \mathrm{F} / \mathrm{M} \text { ratio } 10\end{array}$ \\
\hline \multirow[t]{2}{*}{ Total solid } & Rice husk & $\begin{array}{l}\mathrm{SS}-\mathrm{AD} \text { on } \mathrm{TS} 17-23 \%, \\
\mathrm{C} / \mathrm{N} \text { ratio } 25\end{array}$ & $\begin{array}{l}\text { The best biogas } \\
\text { productivity at TS } 23 \% \\
\text { per unit volume and TS } \\
17 \% \text { per unit weight } \\
\text { (grams) }\end{array}$ \\
\hline & Rice husk & $\begin{array}{l}\mathrm{SS}-\mathrm{AD} \mathrm{TS} \\
\text { ratio } 20-50,40 \%, \mathrm{C} / \mathrm{N} \\
\mathrm{NaOH} 3 \% \text { and Enzyme } \\
6 \%\end{array}$ & $\begin{array}{l}\text { The best biogas } \\
\text { productivity at TS } 27 \% \\
\text { with a } \mathrm{C} / \mathrm{N} \text { ratio of } 35\end{array}$ \\
\hline
\end{tabular}

\section{Conclusion}

The development of research on biogas production from rice husks based SS-AD has experienced a positive increase in hardness. Studies have been conducted on the pretreatment to other influencing factors. But after the authors describe the latest development of biogas research from rice husk, there are still some variables that have not been tested such as physical treatment, the influence of temperature, $\mathrm{pH}$ and alkalinity. Based on this review, further research is needed to complete a number of variables that have not been carried out so that it is expected that the development of biogas production from rice husk based SS-AD can move toward larger scales such as pilot scale and industrial scale.

\section{References}

[1] K. Pertanian, "Produksi, Luas Panen dan Produktivitas Padi di Indonesia, 2014 2018," p. 2018 (2018)

[2] M. Rusono, N., Suanri, A., Candradijaya, A., Muharam, A., Martino, I., Tejaningsih., Hadi, P. U., Susilowati S. H., Maulana, "Rencana Pembangunan Jangka Menengah Nasional (RPJMN) Bidang Pangan dan Pertanian 2015-2019 (National Medium Term Development Plan (RPJMN) for Food and Agriculture 2015-2019)," pp. 12-13 (2015)

[3] Budiyono, I. Syaichurrozi, and S. Sumardiono, "Biogas production kinetic from vinasse waste in batch mode anaerobic digestion," World Appl. Sci. J., vol. 26, no. 11, pp. 1464-1472 (2013)

[4] T. Al Seadi et al., Biogas Handbook (2008)

[5] M. M. Akhand and A. Méndez Blancas, "Optimization of NMMO pre-treatment of straw for enhanced biogas production," no. 4 (2012) 
[6] Syafrudin, W. Dwi Nugraha, S. Sarima Agnesia, H. Hawali Abdul Matin, and Budiyono, "Enhancement of Biogas Production from Rice Husk by $\mathrm{NaOH}$ and Enzyme Pre-treatment," E3S Web Conf., vol. 31, no. December 2016, p. 02002 (2018)

[7] A. Haryanto, F. Marotin, S. Triyono, and U. Hasanudin “ Developing A FamilySize Biogas-Fueled Electricity Generating System,” International Journal of Renewable Energy Development, vol. 6, no. 2, pp. 111-118 (2017)

[8] J. S. Lim, Z. Abdul Manan, S. R. Wan Alwi, and H. Hashim, "A review on utilisation of biomass from rice industry as a source of renewable energy," Renew. Sustain. Energy Rev., vol. 16, no. 5, pp. 3084-3094 (2012)

[9] H. H. A. Matin and H. Hadiyanto, "Optimization of biogas production from rice husk waste by solid state anaerobic digestion (SSAD) using response surface methodology," J. Environ. Sci. Technol., vol. 11, no. 3, pp. 147-156 (2018)

[10] Z. Song, G. Yang, Y. Guo, and T. Zhang, "Comparison of two chemical pretreatments of rice straw for biogas production by anaerobic digestion,"

BioResources, vol. 7, no. 3, pp. 3223-3236 (2012)

[11] W. Zhong, Z. Zhang, Y. Luo, S. Sun, W. Qiao, and M. Xiao, "Effect of biological pre-treatments in enhancing corn straw biogas production," Bioresour. Technol., vol. 102, no. 24, pp. 11177-11182 (2011)

[12] A. M. Mustafa, T. G. Poulsen, Y. Xia, and K. Sheng, "Combinations of fungal and milling pre-treatments for enhancing rice straw biogas production during solid-state anaerobic digestion,” Bioresour. Technol., vol. 224 (2017)

[13] Z. Sapci, "The effect of microwave pre-treatment on biogas production from agricultural straws," Bioresour. Technol., vol. 128, pp. 487-494 (2013)

[14] C. Mirtsou-Xanthopoulou, E. Jurado, I. V. Skiadas, and H. N. Gavala, "Effect of aqueous ammonia soaking on the methane yield and composition of digested manure fibers applying different ammonia concentrations and treatment durations," Energies, vol. 7, no. 7, pp. 4157-4168 (2014)

[15] Y.A.Alemayehu., " Status and Benefits of Renewable Energy Technologies in the Rural Areas of Ethiopia: A Case Study on Improved Cooking Stoves and Biogas Technologies," International Journal of Renewable Energy Development, vol. 4(3), pp. 189-196 (2015)

[16] H. Wang, Y. Pu, A. Ragauskas, and B. Yang, "From lignin to valuable productsstrategies, challenges, and prospects," Bioresour. Technol., vol. 271, no. July 2018, pp. 449-461 (2019)

[17] F. Ahmad, E. L. Silva, and M. B. A. Varesche, "Hydrothermal processing of biomass for anaerobic digestion - A review," Renewable and Sustainable Energy Reviews, vol. 98 (2018)

[18] S. Sumardiono, A. Budi Riyanta, H. Hawali Abdul Matin, T. Djoko Kusworo, B. Jos, and Budiyono, "Increasing biogas production from sugar cane baggase by anaerobic co-digestion with animal manure," MATEC Web Conf., vol. 101, p. 02014 (2017)

[19] X. Ge, F. Xu, and Y. Li, "Solid-state anaerobic digestion of lignocellulosic biomass: Recent progress and perspectives," Bioresour. Technol., vol. 205, pp. 239-249 (2016)

[20] M. Badshah, D. M. Lam, J. Liu, and B. Mattiasson, "Use of an Automatic Methane Potential Test System for evaluating the biomethane potential of sugarcane bagasse after different treatments," Bioresour. Technol., vol. 114, pp. 262-269 (2012) 
[21] W. Dwi Nugraha, Syafrudin, C. Fadhila Keumala, H. Hawali Abdul Matin, and Budiyono, "The Effect of Acid Pre-Treatment using Acetic Acid and Nitric Acid in The Production of Biogas from Rice Husk during Solid State Anaerobic Digestion (SS-AD)," E3S Web Conf., vol. 31, p. 01006 (2018)

[22] S. O-Thong, K. Boe, and I. Angelidaki, "Thermophilic anaerobic co-digestion of oil palm empty fruit bunches with palm oil mill effluent for efficient biogas production," Appl. Energy, vol. 93, pp. 648-654 (2012)

[23] L. Yang, F. Xu, X. Ge, and Y. Li, "Challenges and strategies for solid-state anaerobic digestion of lignocellulosic biomass," Renewable and Sustainable Energy Reviews, vol. 44 (2015)

[24] Syafrudin, W. Dwi Nugraha, H. Hawali Abdul Matin, and Budiyono, "The effect of enzymatic pre-treatment and $\mathrm{c} / \mathrm{n}$ ratio to biogas production from rice husk waste during solid state anaerobic digestion (SS-AD)," MATEC Web Conf., vol. 101, p. 02016 (2017)

[25] Syafrudin, W. D. Nugraha, H. H. A. Matin, L. G. Kencanawardhani, and Budiyono, "The Influence of Enzymatic Pre-treatment and Food to Microorganism (F/M) Ratio to Biogas Production from Rice Husk Waste During Solid State Anaerobic Digestion (SS-AD)," Adv. Sci. Lett., vol. 23, no. 6, pp. 5687-5690 (2017)

[26] Y. Li, S. Y. Park, and J. Zhu, "Solid-state anaerobic digestion for methane production from organic waste," Renew. Sustain. Energy Rev., vol. 15, no. 1, pp. 821-826 (2011)

[27] J. Ye et al., "Improved biogas production from rice straw by co-digestion with kitchen waste and pig manure," Waste Manag., vol. 33, no. 12, pp. 2653-2658 (2013)

[28] K. Risberg, L. Sun, L. Levén, S. J. Horn, and A. Schnürer, "Biogas production from wheat straw and manure - Impact of pre-treatment and process operating parameters," Bioresour. Technol., vol. 149, pp. 232-237 (2013)

[29] A. N. Matheri, S. N. Ndiweni, M. Belaid, E. Muzenda, and R. Hubert, "Optimising biogas production from anaerobic co-digestion of chicken manure and organic fraction of municipal solid waste," Renewable and Sustainable Energy Reviews, vol. 80 (2017)

[30] U. C. Okonkwo, E. Onokpite, and A. O. Onokwai, "Comparative study of the optimal ratio of biogas production from various organic wastes and weeds for digester/restarted digester," J. King Saud Univ. - Eng. Sci., vol. 30, no. 2, pp. 123129 (2018)

[31] I. N. Widiasa and S. Johari, "Study on Slaughterhouse Wastes Potency and Characteristic for Biogas Production," Internat. J. Waste Resour., vol. 1, no. 2, pp. 4-7 (2011)

[32] B. Budiyono, I. N. Widiasa, S. Johari, and S. Sunarso, "Increasing Biogas Production Rate from Cattle Manure Using Rumen Fluid as Inoculums," Int. J. Sci. Eng., vol. 6, no. 1, pp. 31-38 (2014)

[33] J. N. Himmelsbach, D. R. Raman, R. P. Anex, R. T. Burns, and C. R. Faulhaber, "Effect of Ammonia Soaking Pre-treatment and Enzyme Addition on Biochemical Methane Potential of Switchgrass," Trans. ASABE, vol. 53, no. 6, pp. 1921-1927 (2013)

[34] T. D. Budiyono and Kusworo, "Biogas Production From Cassava Starch Effluent Using Microalgae As Biostabilisator,” Internat. J. Sci. Eng, vol. 2, no. 1, pp. 4-8 (2011) 
[35] F. A. Purwandari et al., "Pre-treatment of oil palm empty fruit bunch (OPEFB) by N-methylmorpholine-N-oxide (NMMO) for biogas production: Structural changes and digestion improvement," Bioresour. Technol., vol. 128, pp. 461-466 (2013)

[36] S. Tuesorn et al., "Enhancement of biogas production from swine manure by a lignocellulolytic microbial consortium," Bioresour. Technol., vol. 144, pp. 579-586 (2013)

[37] Budiyono, I. Syaichurrozi, and S. Sumardiono, "Effect of total solid content to biogas production rate from vinasse," Int. J. Eng. Trans. B Appl., vol. 27, no. 2, pp. 177-184 (2014)

[38] Y. Lu et al., "Characteristics of hydrogen and methane production from cornstalks by an augmented two- or three-stage anaerobic fermentation process," Bioresour. Technol., vol. 100, no. 12, pp. 2889-2895 (2009)

[39] Syafrudin, W. D. Nugraha, L. G. Ardinata, Indra Hukama Kencanawardhani, H. H. A. Matin, and Budiyono, "The Influence of Total Solid (TS) Content to Biogas Production from Rice Husk Waste During Solid State Anaerobic Digestion (SSAD)," Adv. Sci. Lett., vol. 23, no. 3, pp. 2204-2206 (2017) 